\title{
Globalization and food systems restructuring in the Caribbean region
}

Review by Kristen Lowitt*

McGill University

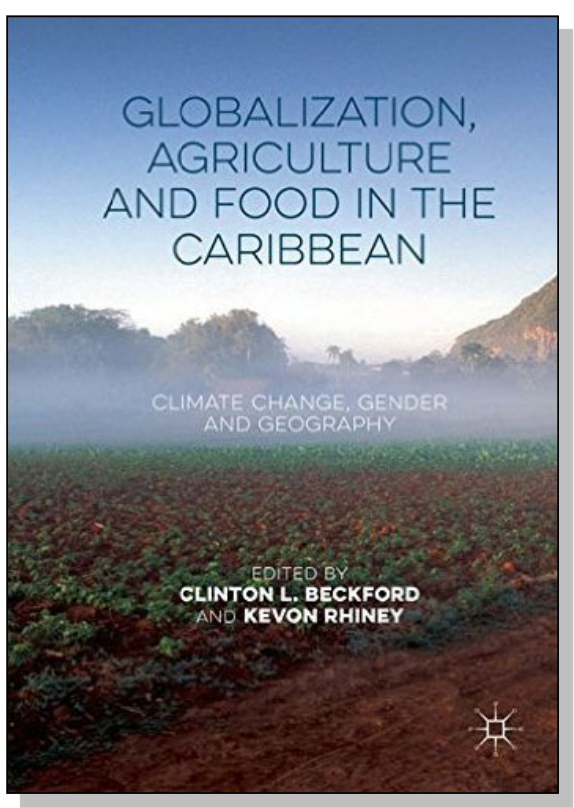

Review of Globalization, Agriculture and Food in the Caribbean: Climate Change, Gender and Geography, edited by Clinton L. Beckford and Kevin Rhiney. (2016). Published by Palgrave MacMillan. Available as hardcover and ebook; 304 pages. Publisher's website: http://www.palgrave.com/us/book/9781137538369

Copyright (C) 2017 by New Leaf Associates, Inc.

$I^{n}$ $\mathrm{n}$ a time of intensifying concerns about food security and climate change, this edited collection by Beckford and Rhiney explores how global economic and environmental change are impacting the food systems of Caribbean Small Island Developing States (SIDS). Although SIDS have been recognized as a "special case" for sustainable development because of their unique susceptibilities to environmental and economic change

* Kristen Lowitt is a postdoctoral fellow in the Department of Natural Resource Sciences at McGill University. Using community-engaged and interdisciplinary research approaches, she explores the relationship between natural resource management and food security in rural and coastal contexts. She can be contacted at kristen.lowitt@mail.mcgill.ca.
(United Nations, 2011), they have been relatively underexplored in contemporary food scholarship. This collection, featuring nine case studies of island food systems based on the research of 10 authors, all with Caribbean roots at the University of the West Indies, is thus a welcome and timely addition to the literature.

One of the most compelling attributes of this book is its local-level look at global challenges. The book offers insights into how globalization is interacting with the social, ecological, and cultural particularities of SIDS to shape food and community outcomes. From indigenous Carib communities in St. Vincent to coffee farmers in Jamaica, the book focuses on the people directly experiencing the 
impacts of globalization and their attempts to carve out livelihoods. While the struggles of these communities are well documented throughout its chapters, the book also offers optimism. I appreciate that most of the chapters offer practical policy strategies for addressing the complex food and agriculture problems examined. The reader also cannot help but feel that the region's diversity of people and landscapes is a tremendous asset. That said, I would have liked the theme of diversity to have been pushed even further in the book. Jamaica is overrepresented in the case studies, and more contributions from the smaller islands would have given a fuller picture of the unique vulnerabilities and strengths of the region.

This edited volume is divided into four parts. Part I: Framing the Discussion contains two chapters. Chapter 1 by Beckford and Rhiney sets up the key themes for the book, presenting an historical overview of the impacts of globalization on the society, culture, and food systems of the region from the early days of European colonization and slavery to the contemporary period characterized by neoliberalism. In Chapter 2, Rhiney explores in greater depth the recent transition that has taken place in many Caribbean states, shifting from primarily agriculture-based economies to servicebased economies heavily reliant on tourism. He concludes with a convincing argument for more integrated strategies that could enhance development synergies between the tourism and agriculture sectors.

Part II: Global Change and Food and Agriculture consists of four chapters examining the effect of globalization on export crops in the region. The first chapter in this section (Chapter 3), by Clarke, looks at the effects on female former sugar workers of the closure of the sugar industry in St. Kitts.

Based in rich qualitative data, Clarke describes how gender norms have limited women's ability to enter small-scale farming as an alternative livelihood strategy in the post-sugar economy. She puts forward a compelling argument for reforming "gender-blind" land and agricultural policies in order to support sustainable livelihood transitions for women. The second chapter in this section (Chapter 4), by Fingal-Robinson, looks at the extent to which fair trade in St. Lucia reduced the negative effects of trade liberalization on banana farmers. Fingal-Robinson presents a balanced assessment of the positive and negative effects of fair trade, determining that while many benefits have been realized, further steps are needed to truly redress inequalities in global trade. The last two chapters in this section (Chapters 5 and 6) focus on Jamaica. In Chapter 5, author Burrell considers how small-scale cane farmers were affected by the loss of preferential markets for sugar and the adaptive strategies they used to sustain their livelihoods. In Chapter 6, author Mighty looks at the coffee industry. Presenting the perspectives of processors, dealers, and farmers as they deal with falling global prices for coffee, it is a nice counterpoint to the previous chapters that focused on the farmer level.

Part III: Climate Change and Food and Agriculture consists of four chapters looking at how farmers, fishers, and the agriculture industry perceive the impacts of climate change. Chapter 7 by Smith is significant as it is the only chapter in the book that begins to engage with issues faced by indigenous communities. Chapter 8 by Beckford and Norman is the most technologically focused of the chapters, assessing the capacity of tissue culture and protected agriculture to address growing pest and disease problems for farmers. Chapter 9 by Constable and Chapter 10 by Baptiste focus on small-scale farmers and small-scale fishers in Jamaica, offering a complimentary view of how actors in both these sectors are responding to climate change.

Part IV: Synthesis consists of a chapter by Beckford and Rhiney in which they present a summary of key findings from the book and outline future directions for addressing food and agriculture problems in the region. In the final sections of this chapter, Beckford and Rhiney present strategies for enhancing agricultural resilience, focusing on the themes of climate-smart agriculture, community adaptation strategies, and gender. Unfortunately, these divisions seem artificial given that the earlier chapters in the book clearly indicated the interconnected nature of climate, community, social, and economic challenges. While some valuable strategies are put forward, I would have liked to have seen the 
authors put together a more holistic list of strategies for resilient agriculture in which gender and community are cross-cutting themes rather than separate considerations.

This book is a valuable resource for scholars, policy-makers, and practitioners interested in the complex relationships between environment, food, and society in the Caribbean. While the book is clearly relevant to those interested in Caribbean agriculture and tropical geographies, it is also of value to those studying food systems more broadly, as the small islands described in this volume are, in many ways, microcosms of the tendencies and contradictions inherent in globalizing food systems.

\section{Reference}

United Nations. (2011). Small Island Developing States: Small islands big(ger) stakes. New York: United Nations Office of the High Representative for the Least Developed Countries, Landlocked Developing Countries and Small Island Developing States. Retrieved from http://www.un.org/ohrlls 